\title{
Effect of Operational Parameter on Loss of Sheath and Power Consumption of Arecanut Sheath Shredder
}

\author{
Shashikumar", D.J. Shrinivasa, M. Anantachar and M. Veerangouda \\ Department of Farm Machinery and Power Engineering, CAE, University of Agricultural \\ Sciences, Raichur, Karnataka, India \\ *Corresponding author
}

\section{A B S T R A C T}

\begin{tabular}{|l|}
\hline Key w or d s \\
Arecanut sheath, \\
Arecanut sheath \\
shredder, Fodder, \\
Cattles. \\
\hline Article Info \\
\hline Accepted: \\
17 September 2017 \\
Available Online: \\
10 October 2017 \\
\hline \hline
\end{tabular}

Arecanut palm has some beneficial parts, except arecanut as a main produce such as husk, leaves and sheath which can be used for different purpose. Among those, arecanut sheath is one of the raw materials obtained from the arecanut palm. It is mainly used for commercial plate making. But recently the arecanut sheath was investigated to use as a dry fodder for cattle. Therefore, electric motor operated arecanut sheath shredder has been designed for chopping of arecanut sheath into small pieces suitable for animal fodder. The performance of arecanut sheath shredder was evaluated at three different cylindrical cutterhead speeds $(13.1,15.71$ and $\left.18.33 \mathrm{~m} \mathrm{~s}^{-1}\right)$, three feed roller speeds $\left(0.28,0.36\right.$ and $\left.0.45 \mathrm{~m} \mathrm{~s}^{-1}\right)$ and numbers of knives $(2,3$ and 4$)$ was used, the effect of these operational parameters on percentage loss of sheath and power consumption was determined.

\section{Introduction}

Arecanut leaf sheath is obtained from the arecanut palm (Areca catechu Linn) is highly heterogeneous having variations in structure, shape and thickness. The rear end is thicker and the two edges are thinner. Sheath of arecanut tree is a hard material (good tensile strength), slow in bio-degradation and has low calorific value. Quality of areca leaf sheath varies with locations and seasons (Kalita et al., 2008). Leaf sheath completely encircles the stem forming a protective covering for the developing inflorescence. Freshly fallen sheaths contain 55-60 per cent moisture. This reduces to 11-16 per cent after drying in open, under shade for 5-6 days. The sheath of an adult palm shows a concavity in the center.
The outer surface of the sheath is greenish or brown, waxy and tough, while the inner surface is creamy in color and has a natural glossy finish. The constituents of the leaf sheaths are cellulose - 43 per cent, crude fibre - 33 per cent and ash - 5 per cent (Biddappa, 1960). In certain regions of Kerala and Dakshina Kannada, leaf sheath is also used as cattle feed by cutting of sheath into small pieces using kathi (sharp edged straight blade hand tool) and machets (Bavappa, et al., 1982).

In India, arecanut is considered as a commercial crop, because, of its higher economic profitability and relatively low 
investment many farmers have replaced paddy cultivation with arecanut, resulting in shortage of paddy straw for its use as animal fodder. Recently, some researcher has been found that the arecanut sheath can be used as a dry fodder for cattle, as an alternative to paddy straw. But, the available machinery for chop making have been tried to chop the arecanut sheath into suitable fodder size. However, due to its physical and biological characteristics of the arecanuts heath, none of them were found suitable to get desired size (Gaikwad and Bhargav, 2012). Hence, keeping the above factors in view, an attempt has been made to develop and evaluate an arecanut sheath shredding machine for making arecanut sheath into suitable fodder size for animals.

\section{Materials and Methods}

The experiments were conducted at different levels of independent parameters viz., cylindrical cutterhead speed, feed rollerspeed and number of knives. In order to chopping of arecanut sheath, the required cylindrical cutter head speed of 13.1 to $18.33 \mathrm{~ms}^{-1}$ and feed roller speed of 0.28 to $0.45 \mathrm{~ms}^{-1}$ with 2 to 4knives was selected. The research was conducted in order to determine the percentage loss of sheath and power consumption of shredder after chopping of sheath by developed arecanut sheath shredder. The laboratory trials were carried out at College of Agricultural Engineering, University of Agricultural Sciences, Raichur during 2014-15. The samples of arecanut sheath can be brought from the Sirsitaluk, Dakshinakannada, Karnataka. The performance evaluation of arecanut sheath shredderwas carried out one hour duration at specified cylindrical cutter head speed, feed rollerspeed and varied number of knives. During the evaluation, a sample was collected from chop outlet for further analysis. The procedure used for evaluating arecanut sheath shredder is given below.

\section{Percentage loss}

The per cent of arecanut sheath was obtained in the powder form after chopping of arecanut sheath by arecanut sheath shredder was considered as a percentage of loss of arecanut sheath. Percentage loss of arecanut sheath incurred during chopping of sheath can be expressed by using formula (Fayose, 2007).

Percentage $\operatorname{loss}($ percent $)=\frac{\text { Total mass of sample }(\mathrm{kg})-\text { Mass after cutting }(\mathrm{kg})}{\text { Total mass of sample }(\mathrm{kg})} \times 100$

\section{Power consumption $\left(\mathrm{C}_{\mathrm{i}}\right)$}

The power consumption of arecanut sheath shredder can be expressed by using formula

$\mathrm{Ci}=\frac{\text { Amount of material fed, } \mathrm{kg}}{\text { Time taken for feeding, } \mathrm{h} \times \text { Average wattmeter reading, } \mathrm{kW}}$

\section{Results and Discussion}

The performance of arecanut sheath shredder was evaluated under lab conditions. The parameters such as power consumption and percentage loss were recorded during the lab test. Statistical analysis was carried out by using the Stat-Ease version 7 Design-Expert software to study the effect of operational parameters. This program helps to optimize the operational parameters and also this software provides highly efficient design of experiments for factorial designs. A three factor completely randomized block design and factorial variance analysis techniques were used to analyze the effect of feed roller speed, cylindrical cutterhead speed and number of knives on percentage loss of sheath and power consumption of arecanut shredder was determined and explained below.

\section{Percentage of loss}

The effect of cylindrical cutterhead speed, feed roller speed and numbers of knives on percentage of loss and analysis of variance for percentage of loss were presented in Tables 1 
and 2, respectively. It was observed that the percentage of loss at feed roller speed of 0.28 , 0.36 and $0.45 \mathrm{~ms}^{-1}$ for cylindrical cutterhead speed of $13.1 \mathrm{~ms}^{-1}$ was found to be $0.5,0.37$ and 0.2 per cent respectively for 2 numbers of knives whereas, for 3 numbers of knives these values were $0.8,0.53$ and 0.31 per cent and for 4 numbers of knives these values were $0.97,0.81$ and 0.62 per cent respectively.

The percentage of loss at feed roller speed of $0.28, \quad 0.36$ and $0.45 \mathrm{~ms}^{-1}$ for cylindrical cutterhead speed of $15.77 \mathrm{~ms}^{-1}$ was found to be $1.03,0.97$ and 0.83 per cent respectively for 2 numbers of knives whereas for 3 numbers of knives these values were 1.4, 1.23 and 1.13 per cent and for 4 numbers of knives these values were $1.63,1.5$ and 1.46 per cent respectively.

It was observed that the percentage of loss at feed roller speed of $0.28,0.36$ and $0.45 \mathrm{~ms}^{-1}$ for cylindrical cutterhead speed of $18.33 \mathrm{~ms}^{-1}$ was found to be $1.7,1.68$ and 1.55 per cent respectively for 2 numbers of knives whereas for 3 numbers of knives these values were $1.89,1.84$ and 1.75 per cent and for 4 numbers of knives these values were 2.13, 1.97 and 1.93 per cent respectively.

The mean values of percentage of loss for 2 numbers of knives was $1.07,1$ and 0.86 per cent at feed roller speed of $0.28 \mathrm{~ms}^{-1}, 0.36 \mathrm{~ms}^{-}$ 1 , and $0.45 \mathrm{~ms}^{-1}$ respectively at all levels of cylindrical cutterhead speeds (13.1, 15.67 and $\left.18.33 \mathrm{~ms}^{-1}\right)$. The mean values of chopping length for 3 numbers of knives was 1.36, 1.2 and 1.06 per cent at feed roller speed of 0.28 $\mathrm{ms}^{-1}, 0.36 \mathrm{~ms}^{-1}$, and $0.45 \mathrm{~ms}^{-1}$ respectively at all levels of cylindrical cutterhead speeds and for 4 numbers of knives $1.57,1.42$ and 1.33 per cent at a feed roller speed of $0.28 \mathrm{~ms}^{-1}$, $0.36 \mathrm{~ms}^{-1}$, and $0.45 \mathrm{~ms}^{-1}$ respectively at all levels of cylindrical cutterhead speeds. The effect of feed roller speeds and numbers of knives on percentage of loss at different cylindrical cutterhead has been presented in Figures 1, 2 and 3 respectively. Table 2 presents the effect of feed roller speed, cylindrical cutterhead speed and number of knives of arecanut sheath shredder on percentage of loss was significantly influenced at 1 per cent level of significance. There was an interaction effect $(\mathrm{C} \times \mathrm{F}, \mathrm{F} \times \mathrm{K}$, $\mathrm{K} \times \mathrm{C}$ and $\mathrm{C} \times \mathrm{F} \times \mathrm{K}$ ) on percentage of loss of arecanut sheath shredder at 1 per cent level of significance.

The percentage of loss decreased as the feed roller speed increased because, the feed rate increases as the feed roller speed increases, thus the number of beating actions on the sheath may be less due to this increasing the chopping length, it means that less powder form of sheath was obtained as a chop and deposited in the bottom of cylindrical cutterhead unit, Hence the percentage of loss decreases at higher feed roller speeds.

The percentage of loss increased as the cylindrical cutterhead speed increased due to the feed rate decreases as the cylindrical cutterhead speed increases thus the number of beating actions on the sheath may be more due to this decreasing the chopping length it means that more powder form of sheath was obtained as a chopped material and some amount deposited in the bottom of cylindrical cutterhead unit, hence the percentage of loss is more towards increasing cylindrical cutterhead speed.

The 4 numbers of knives shows that, the more percentage of loss as compared to 2 and 3 numbers of knives may be due to the beating actions of 4 numbers of knives is more than the 2 and 3 numbers of knives due to this decreasing the chopping length in powder form and deposited in the bottom of cylindrical cutterhead unit, hence the percentage of loss is more for 4 numbers of knives. 
Fig.1 Effect of feed roller speed $(\mathrm{F})$ and number of knives $(\mathrm{K})$ on percentage of loss at $13.1 \mathrm{~m} \mathrm{~s}^{-1}$ cylindrical cutterhead speed (C)

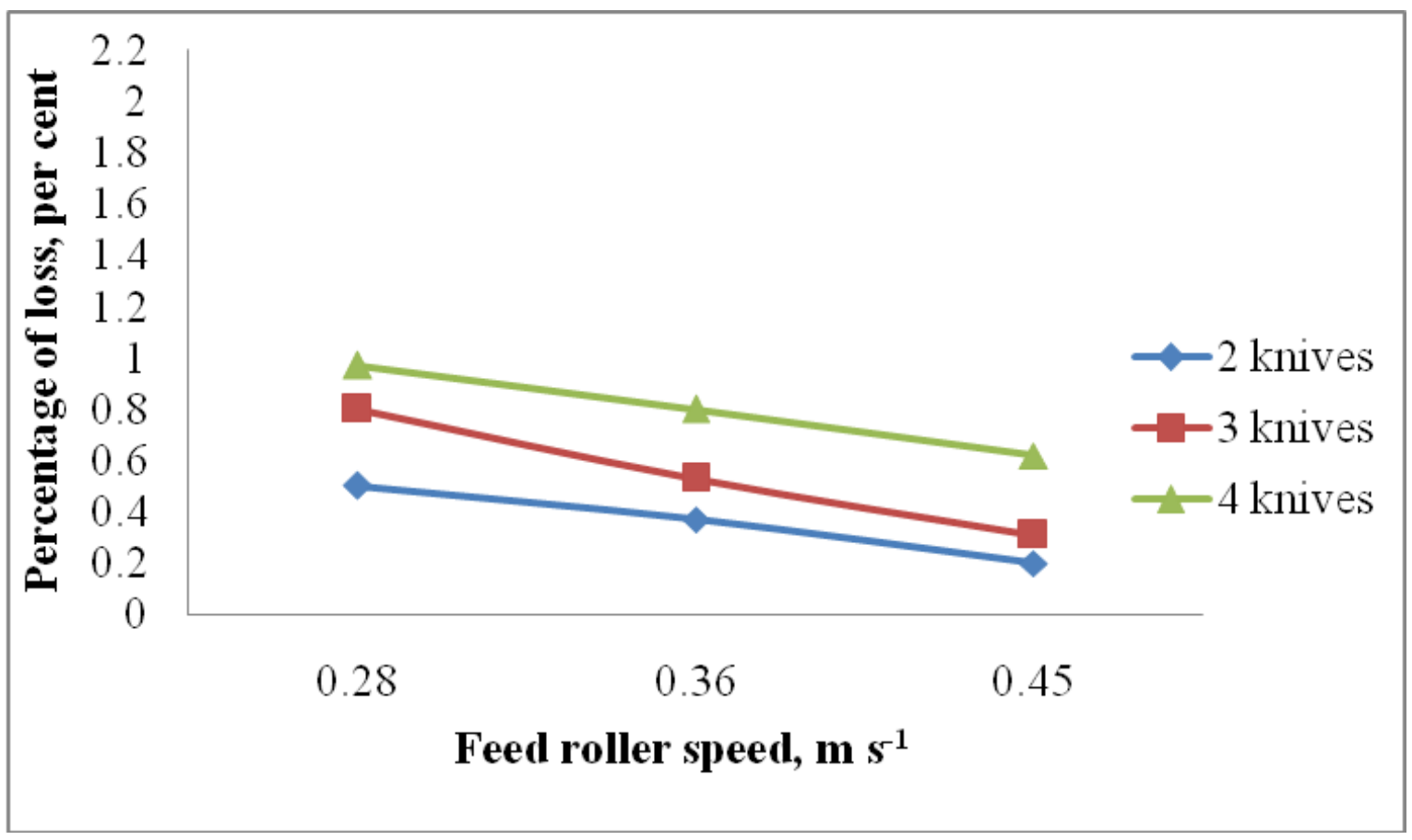

Fig.2 Effect of feed roller speed (C) and number of knives (K) on percentage of loss at $15.71 \mathrm{~m}$ $\mathrm{s}^{-1}$ cylindrical cutterhead speed (C)
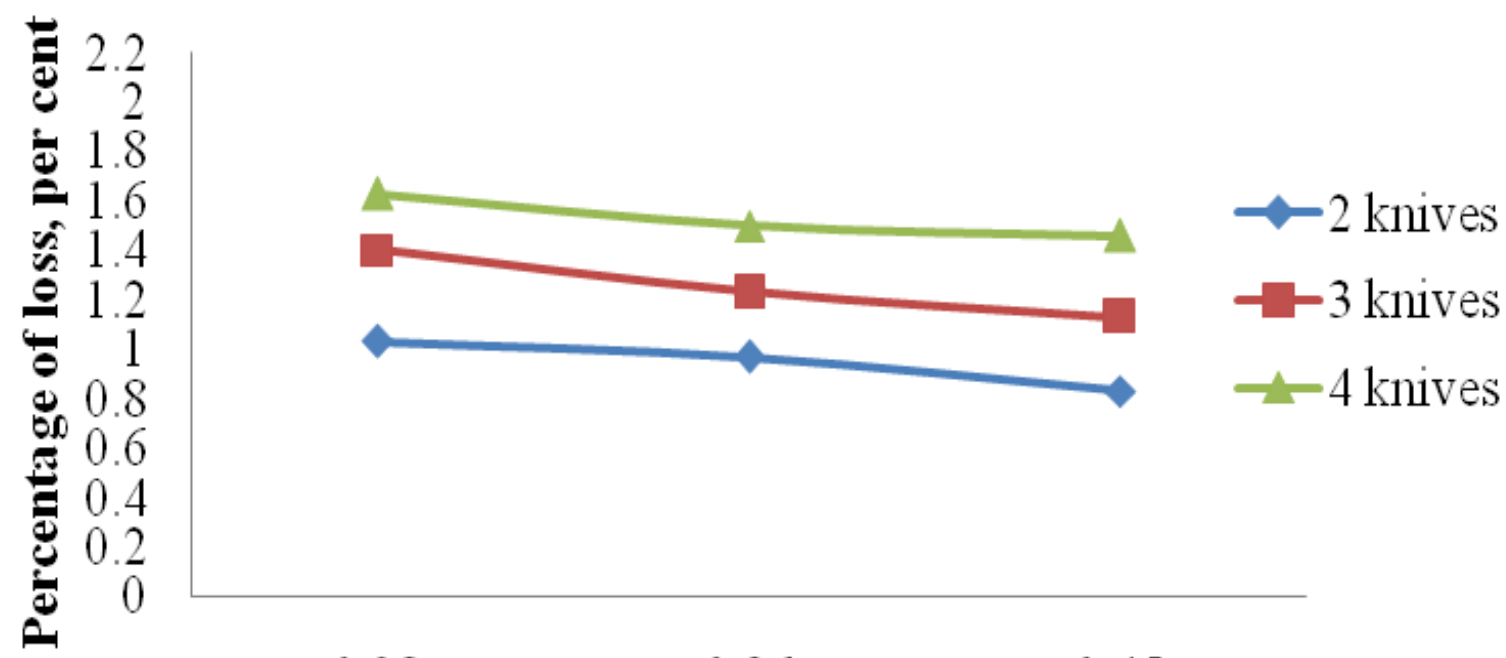

0.28

0.36

0.45

Feed roller speed, $\mathrm{m} \mathrm{s}^{1}$ 
Fig.3 Effect of feed roller speed (F) and number of knives (K) on percentage of loss at $18.33 \mathrm{~m} \mathrm{~s}^{-}$ ${ }^{1}$ cylindrical cutterhead speed (C)

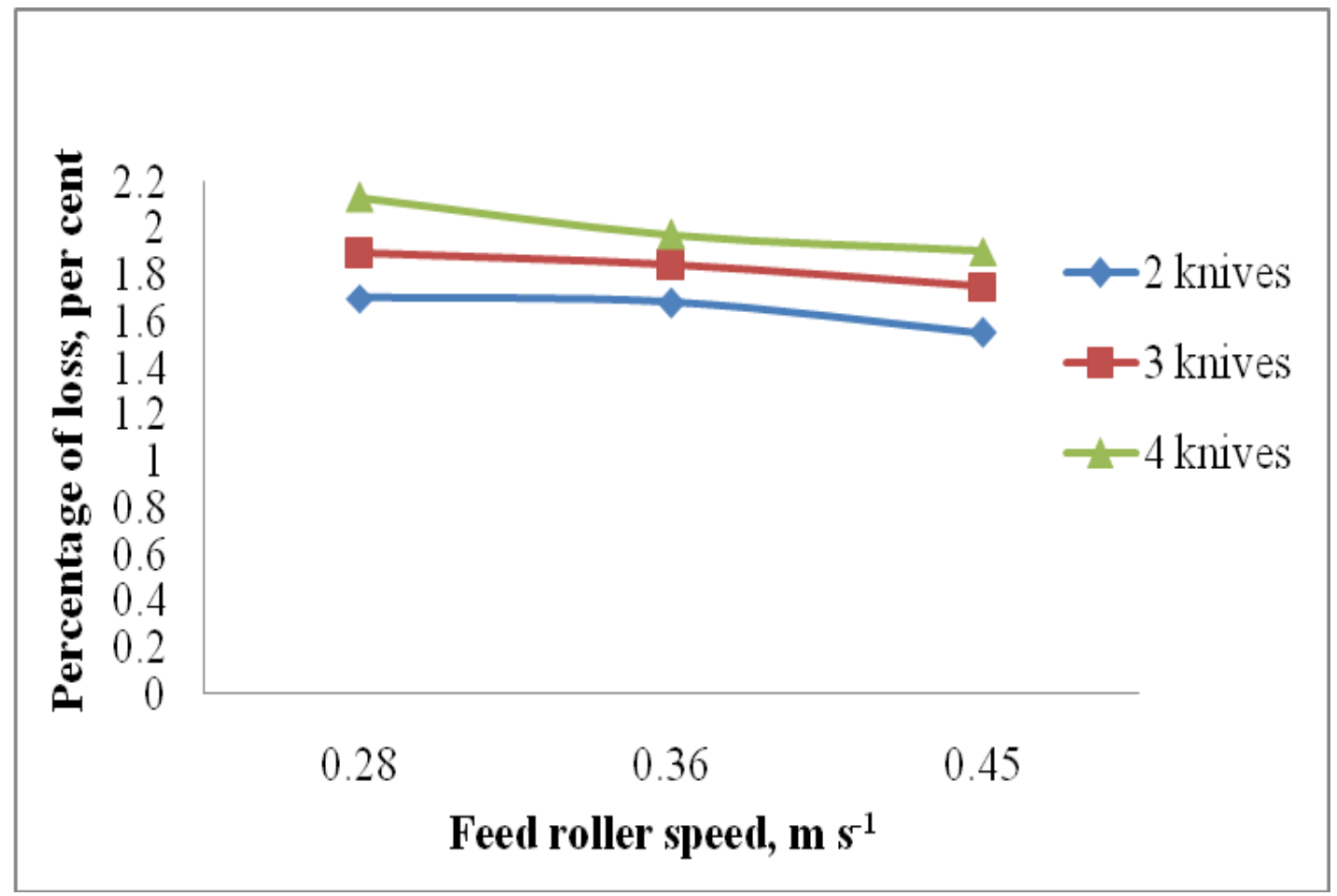

Fig.4 Effect of feed roller speed $(\mathrm{F})$ and numbers of knives $(\mathrm{K})$ on power consumption at $13.1 \mathrm{~m}$ $\mathrm{s}^{-1}$ cylindrical cutterhead speed (C)

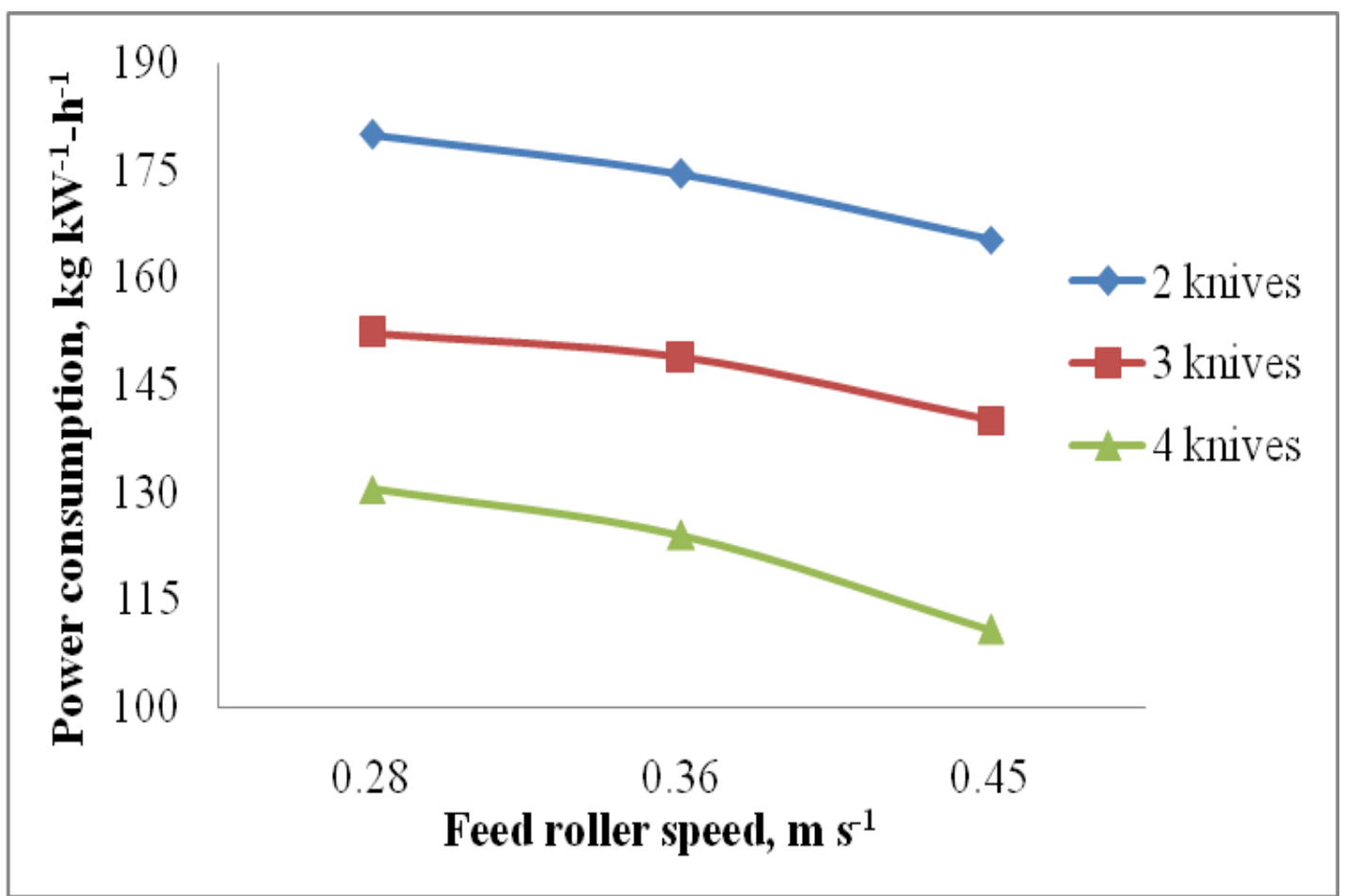


Fig.5 Effect of feed roller speed (F) and numbers of knives $(\mathrm{K})$ on power consumption at 15.71 $\mathrm{m} \mathrm{s}^{-1}$ cylindrical cutterhead speed (C)

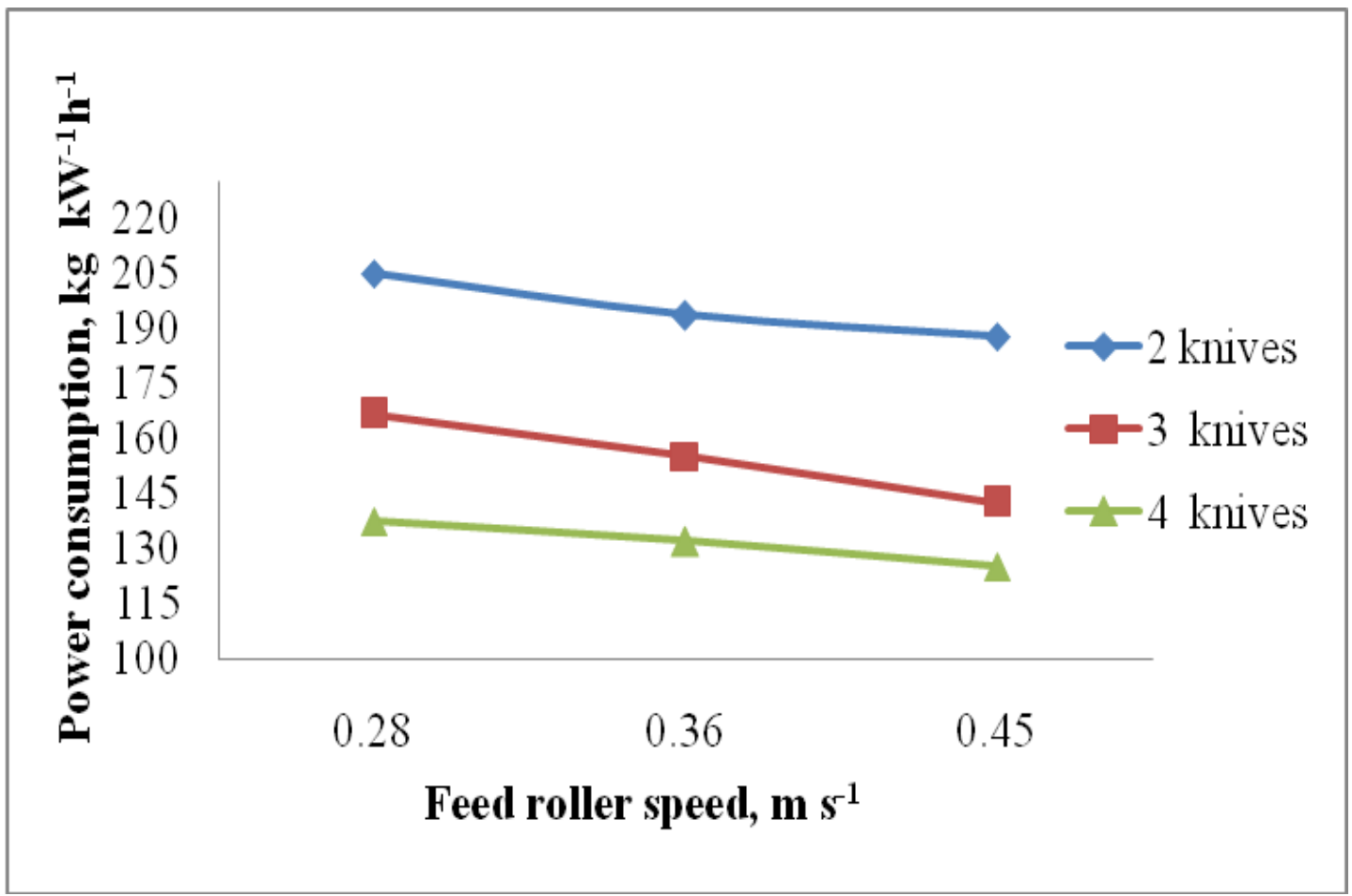

Fig.6 Effect of feed roller speed $(\mathrm{F})$ and numbers of knives $(\mathrm{K})$ on power consumption at 18.33 $\mathrm{m} \mathrm{s}^{-1}$ cylindrical cutterhead speed (C)

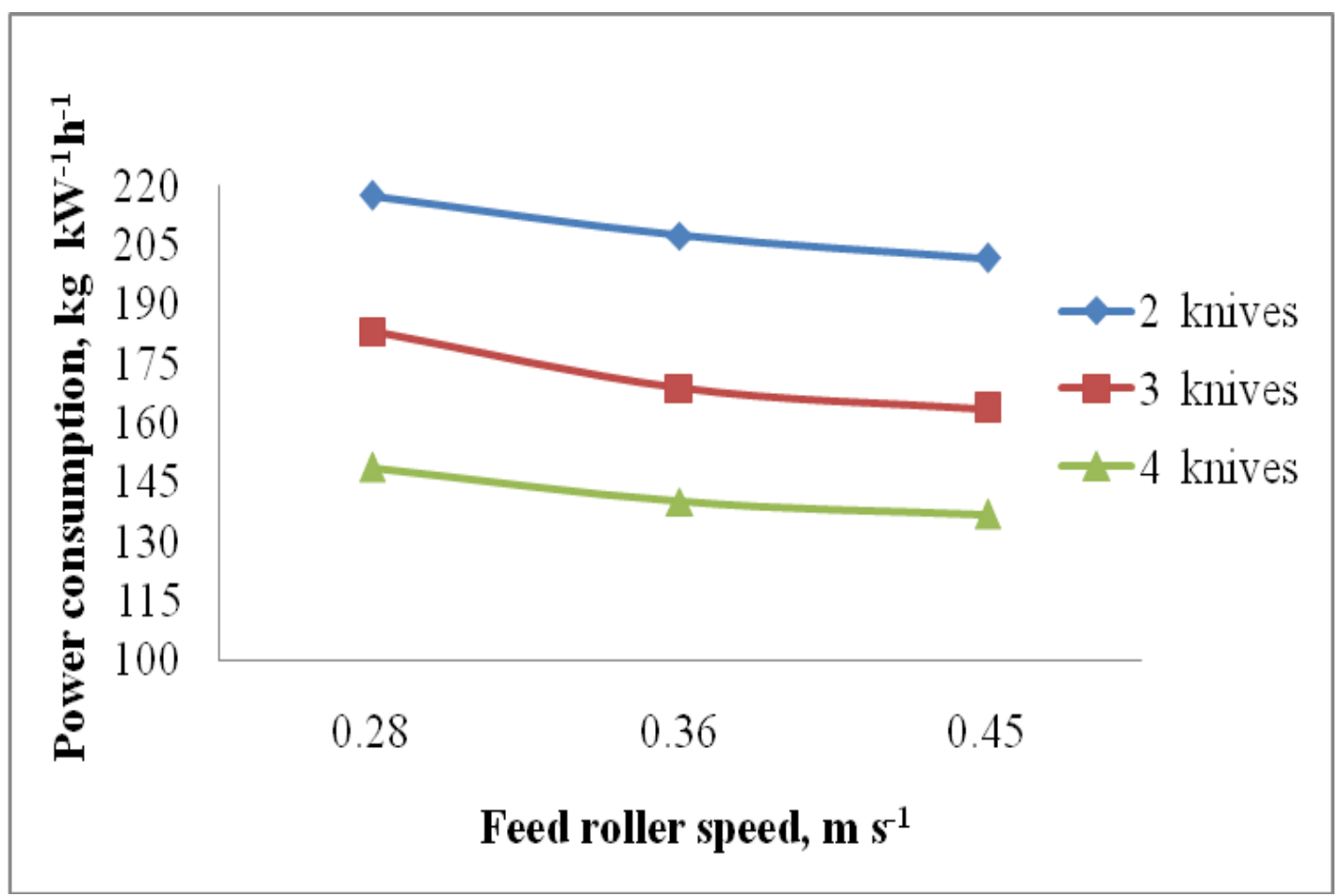


Table.1 Effect of cylindrical cutterhead speed (C), feed roller speed (F) and numbers of knives (K) on percentage of loss

\begin{tabular}{|c|c|c|c|c|c|}
\hline \multirow{3}{*}{$\begin{array}{l}\text { Sl. } \\
\text { No }\end{array}$} & \multirow{3}{*}{$\begin{array}{c}\text { Cylindrical } \\
\text { cutterhead speed } \\
(\mathrm{C}), \mathrm{m} \mathrm{s}^{-1}\end{array}$} & \multirow{3}{*}{$\begin{array}{c}\text { Feed roller } \\
\text { speed }(\mathbf{F}), \\
\mathrm{m} \mathrm{s}^{-1}\end{array}$} & \multirow{2}{*}{\multicolumn{3}{|c|}{$\begin{array}{c}\text { Percentage of loss, per cent } \\
\text { Numbers of knives }(\mathbf{K})\end{array}$}} \\
\hline & & & & & \\
\hline & & & 2 & 3 & 4 \\
\hline \multirow{3}{*}{1} & \multirow{3}{*}{13.1} & 0.28 & 0.50 & 0.80 & 0.97 \\
\hline & & 0.36 & 0.37 & 0.53 & 0.8 \\
\hline & & 0.45 & 0.2 & 0.31 & 0.62 \\
\hline \multirow{3}{*}{2} & \multirow{3}{*}{15.71} & 0.28 & 1.03 & 1.40 & 1.63 \\
\hline & & 0.36 & 0.97 & 1.23 & 1.50 \\
\hline & & 0.45 & 0.83 & 1.13 & 1.46 \\
\hline \multirow{3}{*}{3} & \multirow{3}{*}{18.33} & 0.28 & 1.7 & 1.89 & 2.13 \\
\hline & & 0.36 & 1.68 & 1.84 & 1.97 \\
\hline & & 0.45 & 1.55 & 1.75 & 1.93 \\
\hline
\end{tabular}

Table.2 Analysis of variance for percentage of loss

\begin{tabular}{|c|c|c|c|c|}
\hline SV & DF & SS & MSS & F \\
\hline Treatment & 26 & 169.68 & 6.52 & $50.24 *$ \\
\hline Cylindrical cutterhead speed (C) & 2 & 55.30 & 27.65 & $212.90 *$ \\
\hline Feed roller speed (F) & 2 & 3.89 & 1.94 & $14.97 *$ \\
\hline Numbers of knives (K) & 2 & 98.80 & 49.40 & $380.36^{*}$ \\
\hline $\mathbf{C} \times \mathbf{~ F}$ & 4 & 1.73 & 0.43 & $3.34 *$ \\
\hline $\mathbf{C} \times \mathbf{K}$ & 4 & 5.72 & 1.43 & $11.02^{*}$ \\
\hline $\mathbf{F} \times \mathbf{C}$ & 4 & 1.47 & 0.36 & $2.83 *$ \\
\hline $\mathbf{C} \times \mathbf{F} \times \mathbf{K}$ & 8 & 2.74 & 0.34 & $2.64 *$ \\
\hline Error & 54 & 7.01 & 0.12 & \\
\hline Total & 80 & 176.69 & & \\
\hline
\end{tabular}

$\mathrm{CV}=5.66$

$\mathrm{SD}=0.36$

$*=$ Significant at 1 per cent level

Table.3 Effect of cylindrical cutterhead speed (C), feed roller speed (F) and numbers of knives $(\mathrm{K})$ on power consumption

\begin{tabular}{|c|c|c|c|c|c|}
\hline \multirow{3}{*}{ Sl. No } & \multirow{3}{*}{$\begin{array}{c}\text { Cylindrical } \\
\text { cutterhead speed } \\
(\mathrm{C}), \mathrm{m} \mathrm{s}^{-1}\end{array}$} & \multirow{3}{*}{$\begin{array}{c}\text { Feed roller } \\
\text { speed (F), } \\
\text { ms }^{-1}\end{array}$} & \multirow{2}{*}{\multicolumn{3}{|c|}{$\begin{array}{c}\text { Power consumption, } \mathrm{kg} \mathrm{kW}^{-1}-\mathrm{h}^{-1} \\
\text { Numbers of knives }(\mathrm{K})\end{array}$}} \\
\hline & & & & & \\
\hline & & & 2 & 3 & 4 \\
\hline \multirow{3}{*}{1} & \multirow{3}{*}{13.1} & 0.28 & 179.97 & 152.26 & 130.40 \\
\hline & & 0.36 & 174.46 & 148.77 & 124.00 \\
\hline & & 0.45 & 165.30 & 140.09 & 110.82 \\
\hline \multirow{3}{*}{2} & \multirow{3}{*}{15.71} & 0.28 & 205.02 & 166.64 & 137.60 \\
\hline & & 0.36 & 193.67 & 155.13 & 132.04 \\
\hline & & 0.45 & 187.90 & 142.61 & 125.20 \\
\hline \multirow{3}{*}{3} & \multirow{3}{*}{18.33} & 0.28 & 217.39 & 183.12 & 148.84 \\
\hline & & 0.36 & 207.43 & 168.69 & 140.00 \\
\hline & & 0.45 & 201.59 & 163.61 & 136.91 \\
\hline
\end{tabular}


Table.4 Analysis of variance for power consumption

\begin{tabular}{|c|c|c|c|c|}
\hline SV & DF & SS & MSS & F \\
\hline Treatment & 26 & 98964.08 & 3806.31 & $11.08^{*}$ \\
\hline Cylindrical cutterhead speed (C) & 2 & 8256.01 & 4128.00 & $12.01 *$ \\
\hline Feed roller speed (F) & 2 & 8544.15 & 4272.07 & $12.43^{*}$ \\
\hline Numbers of knives (K) & 2 & 45075.45 & 22537.73 & $65.61 *$ \\
\hline $\mathbf{C} \times \mathbf{~ F}$ & 4 & 9943.99 & 2485.99 & $7.23 *$ \\
\hline $\mathbf{C} \times \mathbf{K}$ & 4 & 3722.21 & 930.55 & $2.70 *$ \\
\hline $\mathbf{F} \times \mathbf{C}$ & 4 & 9844.49 & 2461.12 & $7.16^{*}$ \\
\hline $\mathbf{C} \times \mathbf{F} \times \mathbf{K}$ & 8 & 13577.76 & 1697.22 & $4.94 *$ \\
\hline Error & 54 & 18547.15 & 343.46 & \\
\hline Total & 80 & 117511.2 & & \\
\hline
\end{tabular}

$\mathrm{CV}=11.78 ; \mathrm{SD}=18.53 ; *=$ Significant at 1 per cent level

\section{Power consumption}

The effect of cylindrical cutterhead speed, feed roller speed and numbers of knives on power consumption and analysis of variance for power consumption were presented in Tables 3 and 4, respectively and discussed below.

It was observed that the power consumption at feed roller speed of $0.28,0.36$ and 0.45 $\mathrm{ms}^{-1}$ for cylindrical cutterhead speed of 13.1 $\mathrm{ms}^{-1}$ was found to be $179.97,174.46$ and $165.3 \mathrm{kgkW}^{-1}-\mathrm{h}^{-1}$ respectively for 2 numbers of knives whereas for 3 numbers of knives these values were 152.26, 148.77 and 140.09 $\mathrm{kgkW}^{-1}-\mathrm{h}^{-1}$ and for 4 numbers of knives these values were $130.4,124$ and $110.82 \mathrm{kgkW}^{-1}-\mathrm{h}^{-1}$ respectively.

The power consumption at feed roller speed of $0.28,0.36$ and $0.45 \mathrm{~ms}^{-1}$ for cylindrical cutterhead speed of $15.77 \mathrm{~ms}^{-1}$ was found to be $205.02,193.37$ and $187.9 \mathrm{kgkW}^{-1}-\mathrm{h}^{-1}$ respectively for 2 numbers of knives whereas for 3 numbers of knives these values were $166.64,155.13$ and $142.61 \mathrm{kgkW}^{-1}-\mathrm{h}^{-1}$ and for 4 numbers of knives these values were 137.60, 132.04 and $125.2 \mathrm{kgkW}^{-1}-\mathrm{h}^{-1}$ respectively. It was observed that the power consumption at feed roller speed of $0.28,0.36$ and $0.45 \mathrm{~ms}^{-1}$ for cylindrical cutterhead speed of $18.33 \mathrm{~ms}^{-1}$ was found to be $217.39,204.43$ and $201.59 \mathrm{kgkW}^{-1}-\mathrm{h}^{-1}$ respectively for 2 numbers of knives whereas for 3 numbers of knives these values were 183.12, 168.69 and $163.61 \mathrm{kgkW}^{-1}-\mathrm{h}^{-1}$ and for 4 numbers of knives these values were 148.84, 140 and $136.91 \mathrm{kgkW}^{-1}-\mathrm{h}^{-1}$ respectively.

The mean values of power consumption for 2 numbers of knives was 200.79, 191.85 and $184.93 \mathrm{kgkW}^{-1}-\mathrm{h}^{-1}$ at feed roller speed of 0.28 $\mathrm{ms}^{-1}, 0.36 \mathrm{~ms}^{-1}$, and $0.45 \mathrm{~ms}^{-1}$ respectively at all levels of cylindrical cutterhead speeds (13.1, 15.67 and $18.33 \mathrm{~ms}^{-1}$ ). The mean values of power consumption for 3 numbers of knives was 167.34, 157.53 and 148.77 $\mathrm{kgkW}^{-1}-\mathrm{h}^{-1}$ at feed roller speed of $0.28 \mathrm{~ms}^{-1}$, $0.36 \mathrm{~ms}^{-1}$, and $0.45 \mathrm{~ms}^{-1}$ respectively at all levels of cylindrical cutterhead speeds and for 4 numbers of knives 138.94, 132 and 90.97 $\mathrm{kgkW}^{-1}-\mathrm{h}^{-1}$ at a feed roller speed of $0.28 \mathrm{~ms}^{-1}$, $0.36 \mathrm{~ms}^{-1}$, and $0.45 \mathrm{~ms}^{-1}$ respectively at all levels of cylindrical cutterhead speeds. The effect of feed roller speeds and numbers of knives on power consumption at different cylindrical cutterhead have been presented in Figures 4, 5 and 6, respectively. Table 4 presents the individual effect of feed roller speed, cylindrical cutterhead speed and number of knives of arecanut sheath shredder on power consumption was significant at 1 
per cent level of significance. There was an interaction effect $(\mathrm{C} \times \mathrm{F}, \mathrm{F} \times \mathrm{K}, \mathrm{K} \times \mathrm{C}$ and $\mathrm{C}$ $\mathrm{x} F \mathrm{x} \mathrm{K}$ ) on power consumption of arecanut sheath shredder at 1 per cent level of significance.

The power consumption in terms of $\mathrm{kgkW}^{-1}$ $\mathrm{h}^{-1}$ decreased as the feed roller speed increased because, as the feed roller speed increased the time taken for feeding decreases, hence the power consumption decreases at higher feed roller speeds at constant feed rate. Similar findings were reported by Ismail et al., (2009). The power consumption increased as the cylindrical cutterhead speed increased due to the time taken for cutting decreases as the cylindrical cutterhead speed increase sat constant feed rate; hence the power consumption is more towards increasing cylindrical cutterhead speed.

Similar findings were reported by Ismail et al., (2009) and El-hanfy and Shalby (2009). The 4 numbers of knives shows that, the less power consumption as compared to 2 and 3 numbers of knives may be due to the time taken for cutting of arecanut sheath decreases for 4 numbers of knives than the 2 and 3 numbers of knives. Similar findings were reported by El-hanfy and Shalby (2009).

The percentage of loss of arecanut sheath shredder was increased as the cylindrical cutterhead speeds and number of knives increased but it is decreased with increase a feed roller speeds. The minimum percentage of loss was observed at $0.45 \mathrm{~ms}^{-1}$ feed roller speed and $13.1 \mathrm{~ms}^{-1}$ cylindrical cutterhead speed with 2 numbers of knives. Power consumption of the arecanut sheath shredder decreased as the feed roller speed and number of knives increased and it has increased when cylindrical cutterhead speed increased. It was observed that, the minimum power consumption was observed at $0.45 \mathrm{~ms}^{-1}$ feed roller speed and $13.1 \mathrm{~ms}^{-1}$ cylindrical cutterhead speed with 4 numbers of knives.

\section{References}

Bavappa, K. V. A., Nair, M. K. and Kumar T. P., 1982, The Arecanut Palm, Central Plantation Crops Research Institute, Kasargod, ICAR Publication. pp. 272273.

Biddappa, K. G., 1960, Utilization of arecanut waste. J. Arecanut., 11: 106-108.

El-Hanfy, E. H., and Shalby, S. A., 2009, Performance evaluation and modification of the Japanese combine chopping unit. $J$. Agric. Eng., 26 (2): 1021- 1035.

Fayose, F. T., 2007, Development of a cutting machine for food materials. J. Agric. Eng. Technol., 15: 58-65.

Gaikwad, B. B., and Bhargav, V. K., 2012a, Size reduction machine for arecanut sheath- enabling alternative animal fodder generation. J. Agrotechnol., 1 (2): 64.

Ismail, F. S. A., Desoukey, N. E., Metwally, M. A. and Nagar, A. B., 2009, Development of a chopping machine for agricultural residue. J. Agric. Mechanization Asia.Afr. Latin Am., 40 (1).

Kalita, P., Dixit, U. S., Mahanta, P. and Saha, U. K., 2008, Anovel energy efficient machine for plate manufacturing from arecanut palm leaf sheath. J. Sci. Ind. Res., 67: 807-811.

\section{How to cite this article:}

Shashikumar, D.J. Shrinivasa, M. Anantachar and Veerangouda, M. 2017. Effect of Operational Parameter on Loss of Sheath and Power Consumption of Arecanut Sheath Shredder. Int.J.Curr.Microbiol.App.Sci. 6(10): 1846-1854.

doi: https://doi.org/10.20546/ijcmas.2017.610.223 